\title{
Semicosciniid bryozoans from the Middle Devonian of Rommersheim (Eifel, Germany)
}

\author{
Andrej Ernst ${ }^{1}{ }^{10}$ \\ Received: 19 April 2021 / Accepted: 9 December 2021 \\ (c) The Author(s) 2022
}

\begin{abstract}
Two bryozoan species belonging to the Family Semicosciniidae Morozova, 1987 are described from the Middle Devonian of the Eifel-Bigeyina winteri (Bornemann, 1884) and Loculipora alvearis (Maurer, 1885). The two species are endemic to the Middle Devonian (Eifelian-Givetian) of the Eifel. Morphology and taxonomical assignment of the studied bryozoans are discussed. The Family Fenestraporidae Xia, 2002 is considered to be invalid.
\end{abstract}

Keywords Devonian $\cdot$ Bryozoa $\cdot$ Fenestrata $\cdot$ Taxonomy $\cdot$ Germany

\section{Introduction}

Bryozoans represent an extant phylum of sessile aquatic animals which show an impressive fossil record from the early Cambrian to the Present. The majority of marine bryozoans possess stable carbonate skeletons which have a high potential of preservation (Smith et al. 2006) and are often abundant among fossils found in marine sediments.

Devonian bryozoans are abundant and diverse worldwide (e.g., Cuffey and McKinney 1979; Bigey 1988). The fenestrate bryozoans were especially successful during this period experiencing rapid diversification during the Early Devonian (e.g., Ernst 2013). They represent a high proportion in fossil assemblages of Devonian sediments in the Eifel area, well known for its paleontological content. Whereas the non-fenestrate bryozoan faunas of the Eifel were extensively described recently (Ernst and Schroeder 2007; Ernst 2008a, 2008b; Ernst et al. 2011, 2012, 2014a, 2014b), fenestrate taxa received only sporadic attention (Ernst 2016, 2020; Ernst and Bohatý 2009). Earlier publications on fenestrate bryozoans from the Middle Devonian of Eifel were those by Nekhoroschev (1928) and Kräusel (1953, 1954, 1956, 1957, 1981).

Handling Editor: Sven Hartenfels.

Andrej Ernst

Andrej.Ernst@uni-hamburg.de

1 Institut für Geologie, Universität Hamburg, Bundesstr. 55, 20146 Hamburg, Germany
The Family Semicosciniidae was established by Morozova (1987: 81) for summarized fenestrate bryozoans with usually robust reticulate colonies of usually conical, rarely fan-like shape, produced by straight or undulating branches connected by dissepiments or fused together by anastomosing. The most significant character of the family are compact autozooecial chambers of predominantly rectangular shape in the mid tangential section and which lack hemisepta. Furthermore, semicosciniid bryozoans lack keel nodes; instead, usually a high and wide median keel between autozooecial rows is developed. In few genera, the median keel is low, but in the majority of representatives of Semicosciniidae, keels are high and often widened in their apical part, in some genera fusing together to form a protective superstructure. Heterozooecia in the form of rounded chambers occur in several genera which are regarded to having a reproductive function (e.g., Morozova 1987, 2001).

The Family Semicosciniidae comprises about 20 genera depending on different perceptions of taxonomists. Gorjunova (1996) did not accept the Semicosciniidae, placing the genera originally placed there by Morozova $(1987,2001)$ into the Family Reteporinidae Dunaeva and Morozova, 1975. However, her concept is hardly acceptable because she placed taxa with undulating branches in the Family Reteporinidae, disregarding their internal morphology. Shape of branches is an external morphological character which appears in unrelated lineages independently (homologous). Xia (2002) erected the Family Fenestraporidae based on the semicosciniid genus Fenestrapora Hall, 1885. However, his definition of the Family Fenestraporidae is solely based on 
the presence of heterozooecia of similar shape (like aviculomorphs in Fenestrapora, see McKinney 1998; Morozova and Lavrentjeva 1998; Ernst 2016) and does not consider any further internal morphological characters. Xia (2002) placed seven genera in the Family Fenestraporidae, all of them having a different internal morphology, as well as different kinds of heterozooecia (Fenestrapora Hall, 1885, Ignotifenestella Morozova, 1974, Mirifenestella Morozova, 1974, Cavernofenestella Morozova, 1974, Permofenestella Morozova, 1974, Polyfenestella Bancroft, 1986, and Aviculofenestella Xia, 2002). Therefore, the Family Fenestraporidae Xia, 2002 is regarded being invalid. The two species of the genus Aviculofenestella have been described from a loose stone block which Xia (2002) regarded being mid-Jurassic in age. However, it appears probable that this block was Palaeozoic in age and tectonically inserted within the Jurassic sediments. Fenestrate bryozoans become extinct at the end of the Permian (e.g., Morozova 2001), and the record of Aviculofenestella from the Jurassic appears dubious.

Devonian was the time of the main distribution of semicosciniid bryozoans. Six genera appeared in the Silurian, and three survived into the Carboniferous. Two genera, Neoreteporina Miller, 1962 and Pseudounitrypa Nekhoroshev, 1926 appeared in the Early Carboniferous, whereas the latter one survived into the Early Permian (Artinskian). However, the majority of genera and their species occurred during the Devonian, with the peak of their distribution in the interval from Emsian to Givetian.

In the Middle Devonian of the Eifel the following semicosciniid genera are known: Schischcatella Waschurova, 1964 (Ernst and Bohatý 2009), Fenestrapora Hall, 1885 (Ernst 2016), Bigeyina Suárez-Andrés and McKinney, 2010 (Kräusel 1953, 1954, 1956), and Loculipora Hall, 1885 (Kräusel 1957, 1981). Furthermore, the genus Semicoscinium Prout, 1859 has been mentioned (in open nomenclature) by Nekhoroshev (1928) and Kräusel (1981) from the Eifel area.

The present paper extends our knowledge about fenestrate bryozoans from the Middle Devonian of the Eifel area and provides a comprehensive description of Bigeyina winteri (Bornemann, 1884) and Loculipora alvearis (Maurer, 1885) from a locality in the vicinity of Brühlborn near Rommersheim in the Eifel, Rhineland-Palatinate, Germany. Both species develop robust conical colonies and are quite common in the Middle Devonian fossil-rich limestones of the Eifel. The high median keels of Bigeyina winteri (Bornemann, 1884) are confined to branches and not interconnected laterally to neighboring keels, whereas those of Loculipora alvearis (Maurer, 1885) are fused together to a solid meshwork. Such structures in fenestrates are regarded as having a protective function (McKinney et al. 2003).

Bigeyina winteri and Loculipora alvearis are endemic to the Middle Devonian (Eifelian-Givetian) of the Eifel. Few species of the genus Bigeyina are known from the Lower Devonian (Pragian) of Czech Republic and Lower to Middle Devonian of Spain (see below). The genus Loculipora has longer range, with several species known from the Silurian of North America and Kazakhstan. Devonian species of Loculipora were recorded from North America and Eurasia (Germany, Tajikistan). Both genera terminate at the end of the Givetian.

\section{Materials and methods}

The studied locality (slope of the former planned roadwork extension of federal road "B 51") is situated in the vicinity of Brühlborn near Rommersheim, Prüm Syncline (50 $12^{\prime}$ 27.14", $6^{\circ} 27^{\prime} 37.45^{\prime \prime}$; Fig. 1). The outcrop contains grayish compact, thin- to medium-bedded limestones of the upper Nims Member of the Junkerberg Formation (Eifelian) (Fig. 2). These limestones are represented by rudstones and bindstones containing brachiopods, corals, stromatolites, echinoderms and abundant bryozoans. Non-fenestrate bryozoans from this locality have been studied by Ernst (2008a).

Collected material represents four separate blocks of limestones less than a fist-size each. From them, 14 randomly oriented thin sections containing fragments of fenestrate bryozoans were prepared. Thin sections were studied in a binocular microscope in transmitted light. Morphological terminology for description of bryozoans is modified from Hageman (1991a, 1991b). The following morphological characters were measured: branch width, fenestrule width, fenestrule length, distance between branch centers, autozooecial aperture width, aperture spacing along branch, aperture spacing diagonally, maximum chamber width, branch thickness including keel, branch thickness without keel (measured from reverse branch surface up to the level of aperture), number of apertures per fenestrule length.

Studied material is housed at the Research Institute and Natural History Museum Senckenberg (Frankfurt am Main, Germany), under numbers SMF 60982-SMF 60995.

\section{Systematic palaeontology}

Phylum Bryozoa Ehrenberg, 1831

Class Stenolaemata Borg, 1926

Superorder Palaeostomata Ma et al., 2014

Order Fenestellida Elias and Condra, 1957

Suborder Fenestellina Astrova and Morozova, 1956

Family Semicosciniidae Morozova, 1987

Genus Bigeyina Suárez-Andrés and McKinney, 2010 


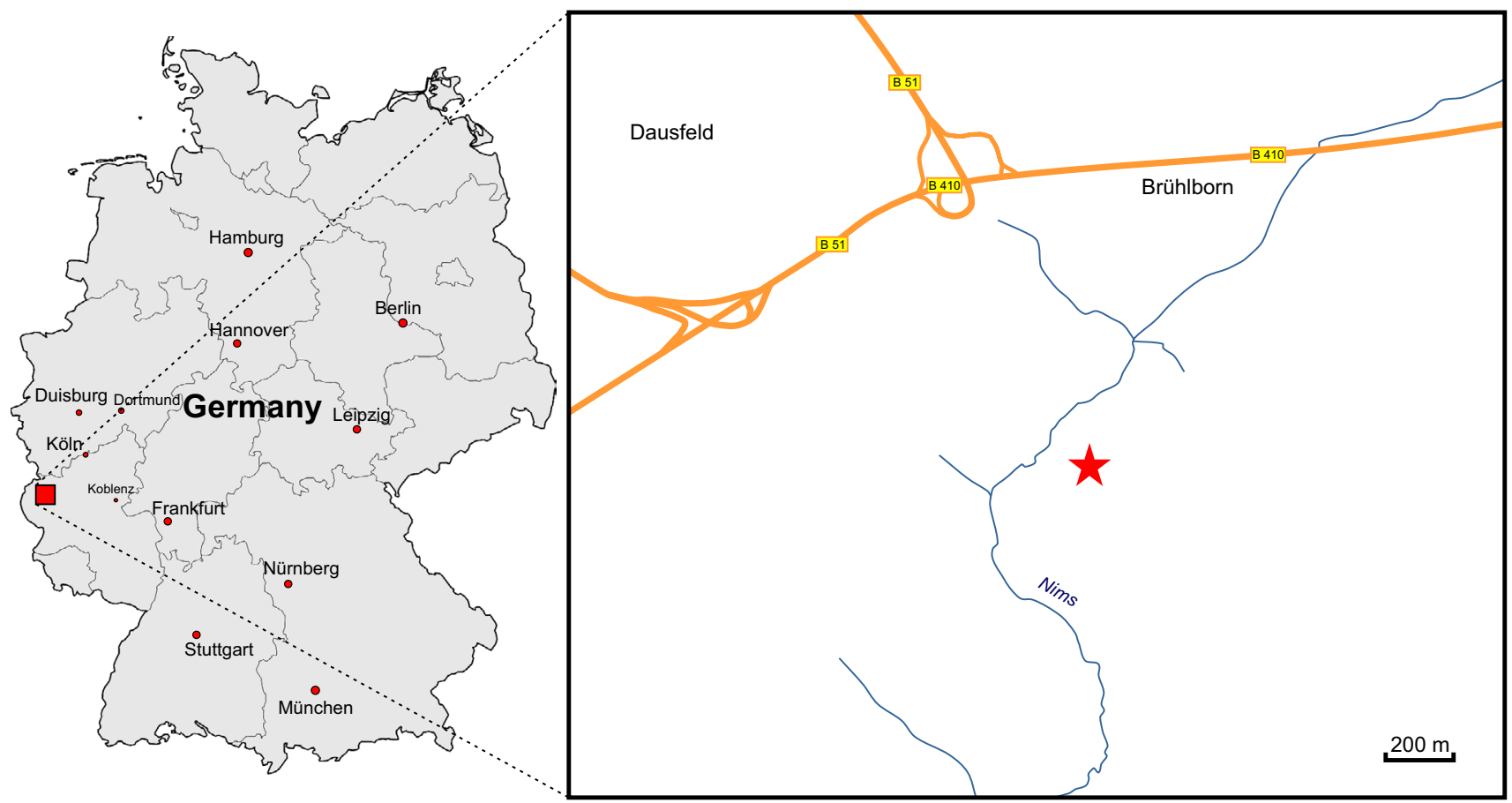

Fig. 1 Map showing the position of the studied locality at Brühlborn near Rommersheim (red asterisk)

Fig. 2 Stratigraphy of the "Type Eifelian Profile" sensu Struve and Werner (1982) reduced, showing the relation of the stratigraphic unit at the studied locality (red asterisk)

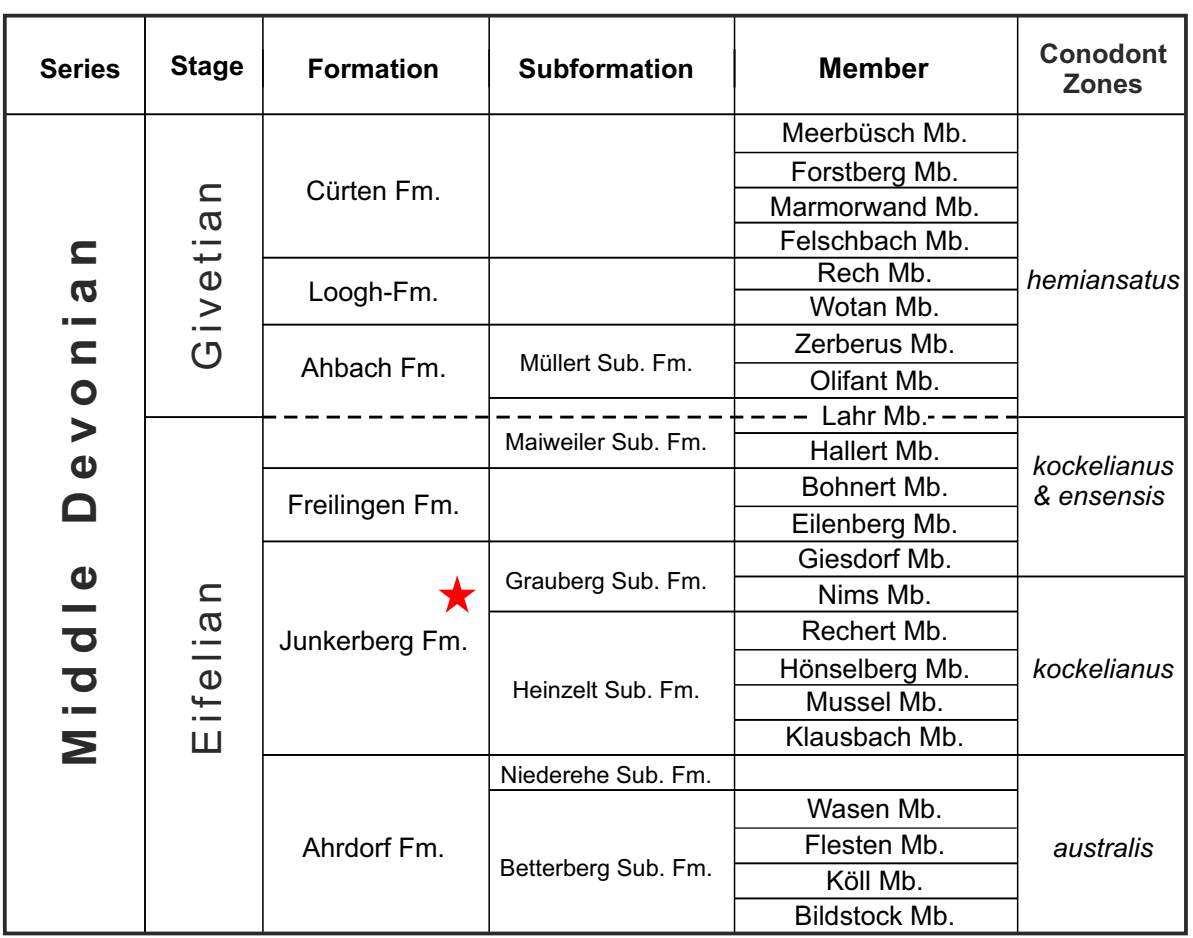


[=Cyclopelta Bornemann, 1884 (non Cyclopelta Amyot and Serville, 1843)].

Type species. Cyclopelta winteri Bornemann, 1884. Geeser Schichten, Eifelian, Middle Devonian; Trilobite Fields west of Gees, Eifel, Rhenish Massif, Germany.

Diagnosis. Colony conical, narrow to broad and flaring; rarely a set of narrow branching, tubular cones. Autozooecial apertures on outer side of cone. Branches minimally to moderately sinuous, linked at intermediate distances by lateral branch expansion and exozonal fusion or by broad, short, regularly spaced dissepiments. Linkages aligned transversely or obliquely to branches; each row of linkages and corresponding parts of branches thickened on reverse surface, forming continuous annular, rarely oblique bands that commonly project into the cone as distally deflected keels. Fenestrules elongate, oval. High keel on obverse surface of branches; granular core of keel apically bifurcated into two symmetrical or asymmetrical, divergent sheets, to form apical lath. Laminar skeleton on keel thickened apically and extending across outer side of lath. Keels not connected to one another, or with sparse to common lateral, bridge-shaped connections above points of connection between underlying branches. Autozooecia arranged in two alternating rows per branch, axially overlapped; axial wall zigzag to sinuous; intermediate to large, cylindrical to irregularly polygonal, height greater than length or width; chamber size greater adjacent to dissepiments, where width commonly greater than length. Hemisepta and other interior structures lacking. Short, direct to laterally oblique distal tube with diameter slightly smaller than endozonal portion of autozooecia. Peristomes thin. Autozooecia apparently monomorphic. Basal, axial and transverse autozooecial walls granular, extremely thin or absent laterally around and near distal tube; autozooecial chambers locally lined by thin inner laminar skeleton. Basal plate flat in branch junctions to strongly concave midway along fenestrules, without longitudinal ridges on reverse side or rarely, with only one developed between branch junctions. Extrazooecial skeleton finely laminate, laminae often obscured, containing abundant, inconspicuous small microstyles. Ancestrula and two or three additional zooecia in contact with substratum. In basal portions of colonies, vesicles also fill interior conical space, space between obverse laths and branches, and fenestrules (adapted after Suárez-Andrés and McKinney 2010).

Comparison. Bigeyina Suárez-Andrés and McKinney, 2010 differs from Semicoscinium Prout, 1859 in having of annular bands developed on the reverse colony surface, in the morphology of the keel with a bifurcated granular core (keel without bifurcation in Semicoscinium), in having a zigzag to sinuous axial wall (straight in Semicoscinium), and in the absence of reproductive heterozooecia (gonozooecia). Bigeyina additionally differs from Fenestrapora in the absence of reproductive heterozooecia and aviculomorphs.

Occurrence. Representatives of the genus Bigeyina SuárezAndrés and McKinney, 2010 were found in the Lower to Middle Devonian of Europe (Czech Republic, Spain, Germany). The following species of this genus are known: $B$. sacculus (Barrande in Počta, 1894) and B. victrola (McKinney and Kříž, 1986) from the Lower Devonian (Pragian) of Czech Republic, B. cantabrica Suárez Andrés and Wyse Jackson, 2017 and B. spinosa Suárez Andrés and Wyse Jackson, 2017 from the Lower Devonian (Emsian) of Spain, B. ibera Ernst, 2012 from the Lower/Middle Devonian (Emsian/Eifelian) of Spain, B. concentrica (Römer, 1852) from the Middle Devonian (Eifelian) of Germany, and $B$. winteri (Bornemann, 1884)) from the Middle Devonian (Eifelian/Givetian) of Germany.

Bigeyina winteri (Bornemann, 1884)

Figure 3a-h; Table 1

1884 Cyclopelta winteri Bornemann: 864-865, pl. 31. 1953 Cyclopelta winteri-Kräusel: 45-62, pls. 1-3, text-figs. 1-7.

non 1998 Cyclopelta winteri-Suárez Andrés: 190-192, pl. 1, figs. 1-3.

2001 Cyclopelta winteri-Morozova: pl. 20, figs. 3, 4.

2010 Bigeyina winteri (Bornemann, 1884)—Suárez Andrés and McKinney: 127, figs. 1, 2.

Material. Two colonies (6 thin sections) SMF 60982-SMF 60987.

Exterior description. Reticulate colonies, conical, frontal surface exterior. Branches intermediate in width, moderately sinuous, intermediately spaced, dichotomously divided, joined by short dissepiments or anastomoses. Autozooecia arranged in two alternating rows on branches, having circular apertures with low peristomes, 4 spaced per length of a fenestrule. Fenestrules oval to lens shaped. Median keel on obverse side of branches straight to slightly sinusoid, high and wide, composed of core of granular skeleton and sheath of laminar skeleton, widening to form apical lath.

Interior description. Autozooecial chambers rectangular in mid tangential section, short and relatively high, with moderately short vestibules. Axial wall between autozooecial rows zigzag in tangential sections, continuing unbroken in superstructure. Hemisepta absent. Internal granular skeleton 
Fig. 3 Bigeyina winteri (Bornemann, 1884): a tangential section of the colony, SMF 60986, b tangential section showing branches, fenestrules and autozooecial chambers, SMF 60986, c-e tangential section showing autozooecial chambers, SMF 60985, f tangential section showing autozooecial apertures chambers, SMF 60986, $\mathbf{g}-\mathbf{h}$ branch transverse section showing autozooecial chambers median keel with dashed nodes, SMF 60983. Scale bars $2 \mathrm{~mm}(\mathbf{a}), 1 \mathrm{~mm}(\mathbf{b})$, $0.5 \mathrm{~mm}(\mathbf{c}, \mathbf{d}, \mathbf{f}, \mathbf{g})$, and $0.2 \mathrm{~mm}$ $(\mathbf{e}, \mathbf{h})$

Table 1 Descriptive statistics of Bigeyina winteri (Bornemann, 1884)
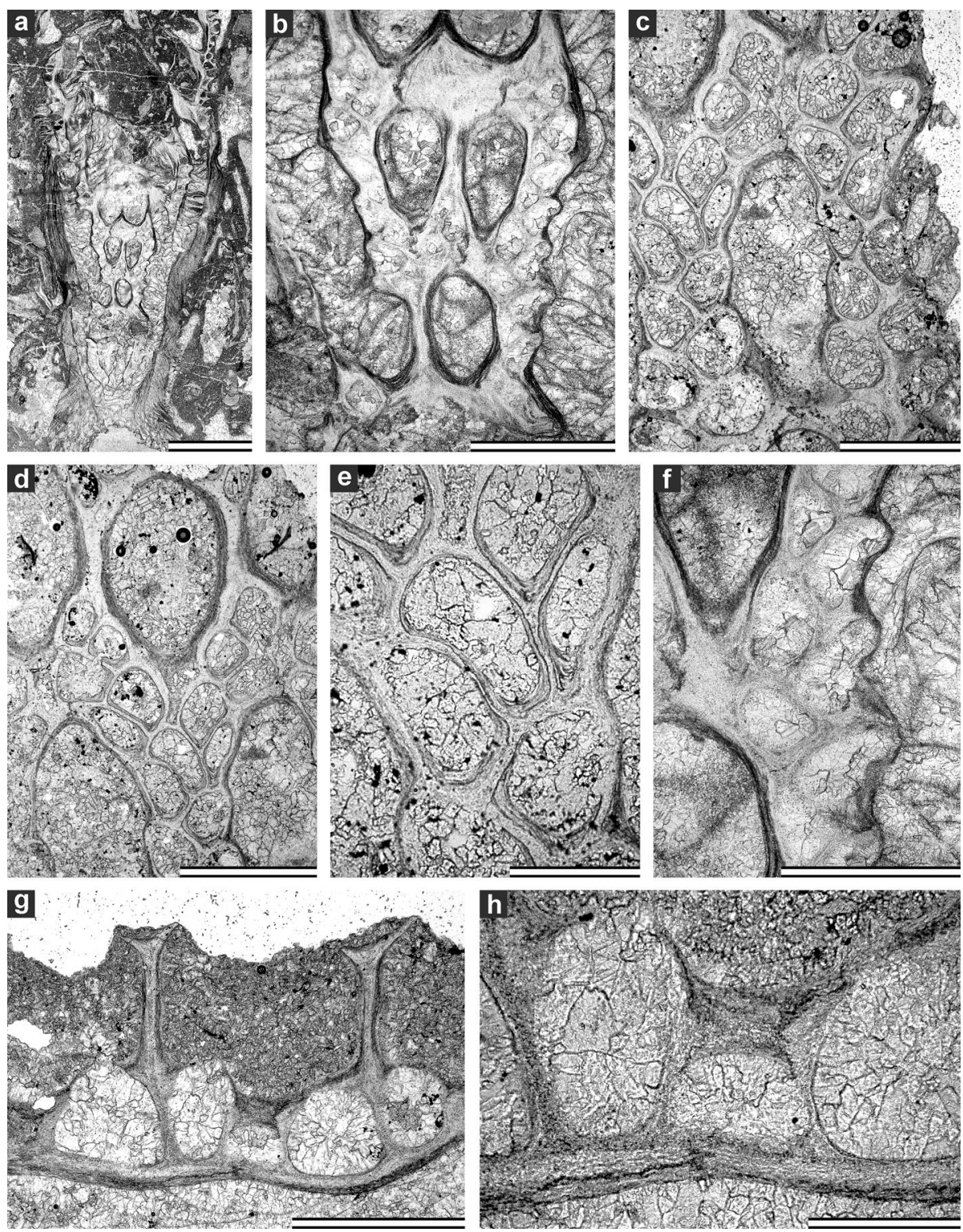

\begin{tabular}{lrllrrr}
\hline & \multicolumn{1}{c}{ N } & X & SD & CV & MIN & MAX \\
\hline Branch width, mm & 16 & 0.34 & 0.050 & 14.60 & 0.28 & 0.45 \\
Fenestrule width, mm & 15 & 0.38 & 0.038 & 9.96 & 0.31 & 0.44 \\
Fenestrule length, mm & 8 & 0.70 & 0.111 & 15.71 & 0.57 & 0.93 \\
Distance between branch centers, mm & 15 & 0.61 & 0.105 & 17.25 & 0.40 & 0.75 \\
Aperture width, mm & 8 & 0.09 & 0.005 & 5.52 & 0.09 & 0.10 \\
Aperture spacing along branch, mm & 5 & 0.28 & 0.041 & 14.43 & 0.23 & 0.33 \\
\hline
\end{tabular}

$N$ number of measurements, $X$ mean, $S D$ sample standard deviation, $C V$ coefficient of variation, $M I N$ minimal value, $M A X$ maximal value continuous with obverse keel, nodes, peristome and across dissepiments. External laminated skeleton well developed, traversed by small microstyles. Microstyles $0.005-0.010 \mathrm{~mm}$ in diameter. Heterozooecia not observed.
Comparison. Bigeyina winteri (Bornemann, 1884) is similar to Bigeyina sacculus (Barrande in Počta, 1894) from the Lower Devonian of the Czech Republic, but differs in having narrower branches (average branch width $0.34 \mathrm{~mm}$ 
vs. $0.40 \mathrm{~mm}$ in B. sacculus) and longer distances between autozooecial apertures (averagely $0.28 \mathrm{~mm}$ vs. $0.25 \mathrm{~mm}$ in B. sacculus).

Occurrence. Material studied in this paper comes from the Upper Nims Member of the Junkerberg Formation (Eifelian, Middle Devonian) at Brühlborn near Rommersheim, Prüm syncline in western Rhenish Massif, Germany. Kräusel $(1953,1954)$ mentioned various records of this species from various localities of Eifelian-Givetian age in the Eifel.

\section{Genus Loculipora Hall, 1885}

Type species. Fenestella perforata Hall, 1885. Middle Devonian; USA (New York).

Diagnosis. Conical or fan-shaped colonies consisting of undulating branches, anastomosing, rarely joined by wide, short or nearly reduced dissepiments with keel. Fenestrules oval to rounded. Keels connected to one another, forming reticulate meshwork connecting outgrowths on top and outgrowths of adjoined branches and dissepiments. Reticulate meshwork analogous to the structure of the main meshwork, but lacking autozooecia. Meshes in the reticulate meshwork correspond to the fenestrules in the main meshwork. Autozooecial apertures on outer side of cone. Autozooecia arranged in two alternating rows per branch, axially overlapped; rectangular to roughly triangular-pentagonal in mid tangential section; axial wall zigzag to sinuous; intermediate to large, cylindrical to irregularly polygonal, height greater than length or width. Hemisepta and other interior structures lacking. Short, direct to laterally oblique distal tube with diameter slightly smaller than endozonal portion of autozooecia. Peristomes thin. Autozooecia apparently monomorphic. Basal, axial and transverse autozooecial walls granular, extremely thin or absent laterally around and near distal tube; autozooecial chambers locally lined by thin inner laminar skeleton. Basal plate moderately to strongly concave. Extrazooecial skeleton finely laminate, laminae often obscured, containing abundant, inconspicuous small microstyles. In basal portions of colonies, vesicles also fill interior conical space, space between obverse laths and branches, and fenestrules.

Comparison. Loculipora Hall, 1885 differs from Isotrypa Hall, 1885 in strongly undulating branches joined mainly by anastomoses. Superstructure in Loculipora is produced by extensions of both median keels and dissepiments, whereas the transverse connections in the superstructure of Isotrypa do not contact with dissepiments. Furthermore, Loculipora has rectangular to roughly triangular-pentagonal autozooecial chambers and zigzag axial wall, whereas autozooecia in
Isotrypa are rectangular with straight axial wall. Loculipora differs from Bigeyina in superstructure morphology which represents reticulate meshwork produced by fused extensions of keels. Keels in Bigeyina are normally not fused together.

Occurrence. Middle Silurian-Middle Devonian; North America, Europe, Middle Asia.

Loculipora alvearis (Maurer, 1885)

Figure $4 \mathrm{a}-\mathrm{i}$; Table 2

1885 Entopora alvearis Maurer: 127-128, pl. 4, figs. 6, 10. 1957 Loculipora alvearis (Maurer, 1885)—Kräusel: 335336, pl. 1, figs. 1-2.

1957 Loculipora (cf.) alvearis (Maurer, 1885)-Kräusel: 337-343, pl. 1, figs. 3-4.

Material. Three colonies (8 thin sections) SMF 60988-SMF 60995.

Exterior description. Narrow conical colonies, consisting of strongly undulating branches, joined by anastomoses. Two rows of autozooecia on branches. Autozooecial apertures circular, with stellate structure, arranged in two alternating rows on branches, having circular apertures with low peristomes, 3-5 spaced per length of a fenestrule. Fenestrules circular to oval. Median keel on obverse side of branches straight, high and wide, composed of core of granular skeleton and sheath of laminar skeleton. Median crests on the superstructure, producing a polygonal pattern. Reverse side smooth.

Interior description. Autozooecial chambers rectangular to roughly triangular-pentagonal in mid tangential section, short and relatively high, with moderately short vestibules. Axial wall between autozooecial rows zigzag in tangential sections, continuing unbroken in superstructure. Hemisepta absent. Internal granular skeleton continuous with obverse keel, nodes, peristome and across dissepiments. External laminated skeleton well developed, traversed by small microstyles. Microstyles $0.005-0.008 \mathrm{~mm}$ in diameter. Heterozooecia not observed.

Comparison. Loculipora alvearis (Maurer, 1885) is similar to L. kschtutica (Waschurova, 1964) from the Lower Devonian of Tajikistan, but differs from it in possessing wider branches (0.31-0.46 $\mathrm{mm}$ vs. $0.30-0.35 \mathrm{~mm}$ in L. kschtutica), as well as in its larger fenestrules (fenestrule width $0.38-0.62 \mathrm{~mm}$ vs. $035-0.45 \mathrm{~mm}$ in L. kschtutica; fenestrule length $0.46-0.82 \mathrm{~mm}$ vs. $0.60-0.70 \mathrm{~mm}$ in L. kschtutica). 
Fig. 4 Loculipora alvearis (Maurer, 1885): a longitudinal section of a basal part of the colony with massive vesicular skeleton, SMF 60993. b tangential section showing branches with autozooecia and reticulate superstructure, SMF 60989, c-f tangential section showing branches, fenestrules, autozooecial chambers and apertures, SMF 60992, g tangential section showing reticulate superstructure, SMF 60993, $\mathbf{h}$ branch transverse section showing autozooecial chambers median keel with nodes fused to superstructure, SMF 60990, i branch transverse section showing autozooecial chambers median keel with nodes fused to superstructure, SMF 60994. Scale bars $5 \mathrm{~mm}(\mathbf{a}, \mathbf{b}), 1 \mathrm{~mm}$ $(\mathbf{b}, \mathbf{g}), 0.5 \mathrm{~mm}(\mathbf{d}, \mathbf{e}, \mathbf{f}, \mathbf{h}, \mathbf{i})$
Table 2 Descriptive statistics of Loculipora alvearis (Maurer, 1885)
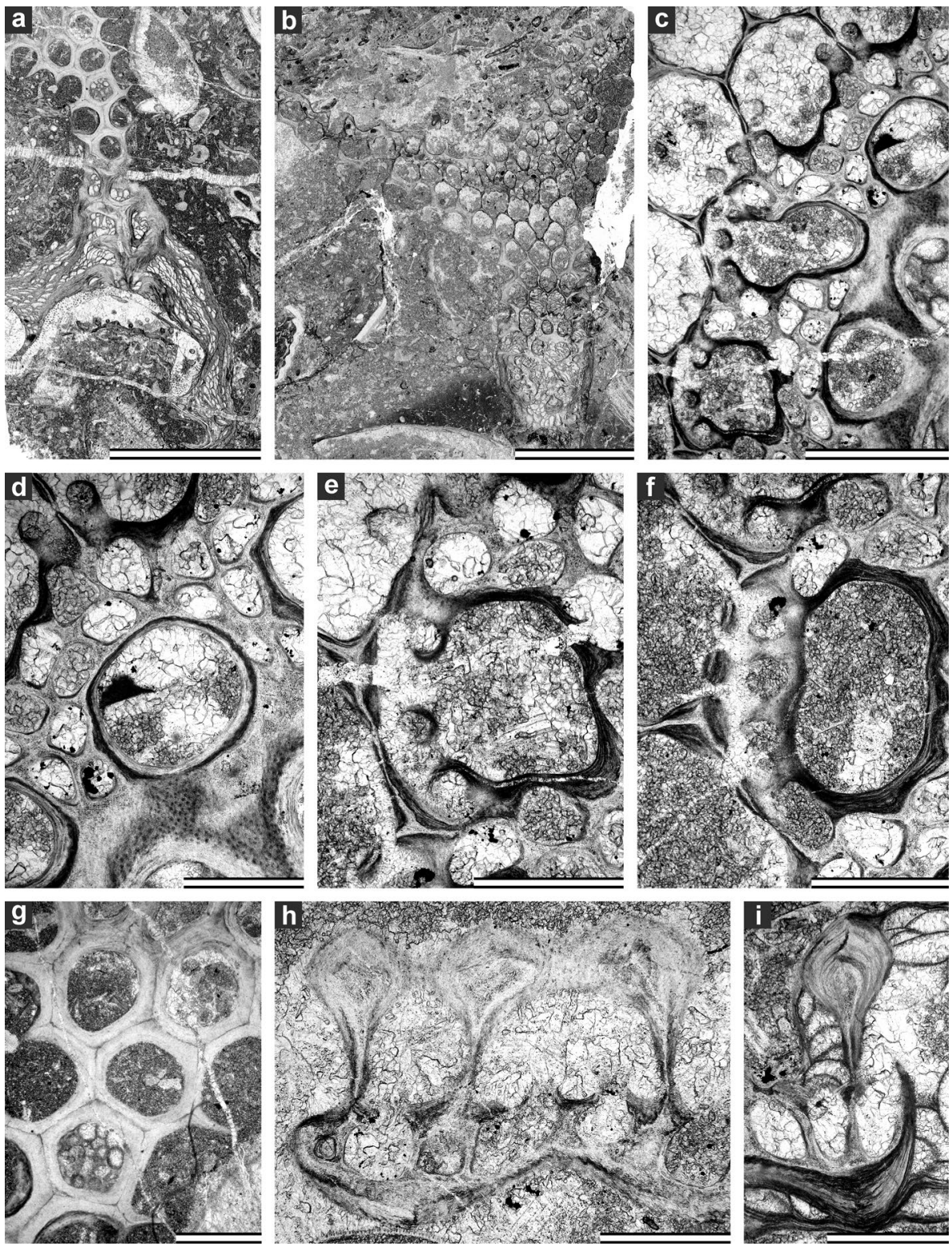

\begin{tabular}{lllllll}
\hline & $N$ & $\mathrm{X}$ & $\mathrm{SD}$ & $\mathrm{CV}$ & $\mathrm{MIN}$ & MAX \\
\hline Branch width, mm & 20 & 0.37 & 0.040 & 10.80 & 0.31 & 0.46 \\
Fenestrule width, mm & 20 & 0.51 & 0.057 & 11.29 & 0.38 & 0.62 \\
Fenestrule length, mm & 20 & 0.67 & 0.099 & 14.76 & 0.46 & 0.82 \\
Distance between branch centers, mm & 20 & 0.88 & 0.110 & 12.48 & 0.71 & 1.10 \\
Aperture width, mm & 20 & 0.10 & 0.006 & 6.47 & 0.09 & 0.12 \\
Aperture spacing along branch, mm & 20 & 0.30 & 0.034 & 11.44 & 0.25 & 0.38 \\
Aperture spacing diagonally, mm & 16 & 0.27 & 0.030 & 11.25 & 0.22 & 0.33 \\
Maximal chamber width, mm & 20 & 0.17 & 0.012 & 7.49 & 0.14 & 0.18 \\
Branch thickness without keel, mm & 20 & 0.44 & 0.032 & 7.24 & 0.40 & 0.50 \\
Branch thickness including keel, mm & 20 & 1.05 & 0.093 & 8.84 & 0.90 & 1.30 \\
Apertures per fenestrule length & 15 & 4.1 & 0.704 & 17.30 & 3.0 & 5.0 \\
\hline
\end{tabular}

Abbreviations as for Table 1 
Occurrence. Stringocephalen-Kalk, Middle Devonian (Givetian); Hainau, Germany. Freilingen Formation, Middle Devonian (Givetian); Dollendorf Syncline, Germany. Calceola-beds, Middle Devonian (Eifelian); Clausthal, Germany. Upper Nims Member of the Junkerberg Formation (Eifelian, Middle Devonian); Brühlborn near Rommersheim, Prüm syncline.

Acknowledgements Jan Bohatý, Wiesbaden, is thanked for providing interesting samples and help in the field. The Deutsche Forschungsgemeinschaft is thanked for financial support (DFG project ER 278/4.1 and 2). Patrick Wyse Jackson, Dublin, and Hans Arne Nakrem, Oslo, are thanked for their helpful and constructive reviews.

Funding Open Access funding enabled and organized by Projekt DEAL.

Open Access This article is licensed under a Creative Commons Attribution 4.0 International License, which permits use, sharing, adaptation, distribution and reproduction in any medium or format, as long as you give appropriate credit to the original author(s) and the source, provide a link to the Creative Commons licence, and indicate if changes were made. The images or other third party material in this article are included in the article's Creative Commons licence, unless indicated otherwise in a credit line to the material. If material is not included in the article's Creative Commons licence and your intended use is not permitted by statutory regulation or exceeds the permitted use, you will need to obtain permission directly from the copyright holder. To view a copy of this licence, visit http://creativecommons.org/licenses/by/4.0/.

\section{References}

Amyot, C.-J.-B., and A. Serville. 1843. Histoire Naturelle des Insectes. Hémiptères. Paris: Libraire Encyclopédique de Roret.

Astrova, A.A., and I.P. Morozova. 1956. About systematics of the Order Cryptostomata. Doklady Akademii Nauk SSSR 110(4): 661-664. (in Russian).

Bancroft, A.J. 1986. A new Carboniferous fenestrate bryozoan genus. Scottish Journal of Geology 22: 96-108.

Bigey, F.P. 1988. Devonian Bryozoa and global events: The Frasnian-Famennian extinction. In The Devonian of the World, Proceedings of the Second International Symposium of the Devonian System, eds. McMillan, N.J., A.F. Embry, and D.J. Glass. Canadian Society of Petroleum Geology, Memoir 14: 53-62.

Borg, F. 1926. Studies on Recent cyclostomatous Bryozoa. Zoologiska Bidrag från Uppsala 10: 181-507.

Bornemann, J.G. 1884. Cyclopelta winteri, eine Bryozoe aus dem Eifeler Mitteldevon. Zeitschrift der Deutschen Geologischen Gesellschaft 36: 864-865.

Cuffey, R.J., and F.K. McKinney. 1979. Devonian Bryozoa. Special Papers in Palaeontology 23: 307-311.

Dunaeva, N.N., and I.P. Morozova. 1975. Revision of the Suborder Fenestelloidea. In Bryozoa 1974, ed. S. Pouyet. Documents de Laboratoires de Géologie Faculté des Sciences de Lyon HS 3(1): 225-233.

Ehrenberg, C.G. 1831. Symbolae Physicae, seu Icones et descptiones Corporum Naturalium novorum aut minus cognitorum, quae ex itineribus per Libyam, Aegiptum, Nubiam, Dongalaam, Syriam, Arabiam et Habessiniam, studia annis 1820-25, redirent. Pars.
Zoologica, 4, Animalia Evertebrata exclusis Insectis, 10 pls. Berolini.

Elias, M.K., and G.E. Condra. 1957. Fenestella from the Permian of west Texas. Geological Society of America Memoir 70: 1-158.

Ernst, A. 2008a. Non-fenestrate bryozoans from the Middle Devonian of the Eifel (western Rhenish Massif, Germany). Neues Jahrbuch für Geologie und Paläontologie, Abhandlungen 250(3): 313-379.

Ernst, A. 2012. Fenestrate bryozoan fauna from the Lower-Middle Devonian of NW Spain. Neues Jahrbuch für Geologie und Paläontologie, Abhandlungen 264(3): 205-247.

Ernst, A. 2013. Diversity dynamics and evolutionary patterns of Devonian Bryozoa. Palaeobiodiversity and Palaeoenvironments 93: 45-63.

Ernst, A. 2016. Fenestrapora (Fenestrata, Bryozoa) from the Middle Devonian of Germany. PalZ. Paläontologische Zeitschrift 90: 19-32.

Ernst, A. 2020. Anastomopora (Fenestrata, Bryozoa) from the Middle Devonian of the Rhenish Massif, Germany. Neues Jahrbuch für Geologie und Paläontologie, Abhandlungen 297(1): 11-26.

Ernst, A., and J. Bohatý. 2009. Schischcatella (Fenestrata, Bryozoa) from the Devonian of the Rhenish Massif, Germany. Palaeontology 52(6): 1291-1310.

Ernst, A., and S. Schröder. 2007. Stenolaemate bryozoans from the Middle Devonian of the Rhenish Slate Massif (Eifel, Germany). Neues Jahrbuch für Geologie und Paläontologie, Abhandlungen 246(2): 205-233.

Ernst, A., P. Königshof, P.D. Taylor, and J. Bohatý. 2011. Microhabitat complexity-an example from Middle Devonian bryozoanrich sediments. Palaeobiodiversity and Palaeoenvironments 91: 257-284.

Ernst, A., P.D. Taylor, J. Bohatý, and P.N. Wyse Jackson. 2012. Homeomorphy in Lunostoma, a new Middle Devonian cryptostome bryozoan. Paläontologische Zeitschrift 86: 135-145.

Ernst, A., J. Bohatý, and P.D. Taylor. 2014a. Botryllopora (Cystoporata, Bryozoa) from the Middle Devonian of Canada and Germany. In Bryozoan Studies 2013, eds. A. Rosso, P.N. Wyse Jackson, and J.S. Porter. Studi Trentini Di Scienze Naturali 94: 101-109.

Ernst, A., P.D. Taylor, and J. Bohatý. 2014b. A new Middle Devonian cystoporate bryozoan from Germany containing a symbiont bioclaustration. Acta Palaeontologica Polonica 59(1): 173-183.

Ernst, A. 2008b. New data on the Middle Devonian Bryozoa of Germany. In Bryozoan Studies 2007: Proceedings of the 14th International Bryozoology Conference, Boone, North Carolina, July 1-8, 2007, eds. S.J. Hageman, M.M. Key Jr., and J.E. Winston. Virginia Museum of Natural History Special Publication 15: 29-36.

Gorjunova, R.V. 1996. Phylogeny of the Paleozoic bryozoans. Trudy Paleontologicheskogo Instituta Rossijskoi Akademii Nauk 267: 1-165. (in Russian).

Hageman, S.J. 1991a. Discrete morphotaxa from a Mississippian fenestrate faunule: Presence and implications. In Bryozoaires actuels et fossil: Bryozoa living and fossil, ed. F.P. Bigey. Bulletin de la Société des Sciences Naturelles de l'Quest de la France. Mèmore HS 1: $147-150$

Hageman, S.J. 1991b. Approaches to systematic and evolutionary studies of perplexing groups: An example using fenestrate Bryozoa. Journal of Paleontology 65: 630-647.

Hall, J. 1885. On the mode of growth and relations of the Fenestellidae. Report of the State Geologist of New York for the Year 1883: $35-45$.

Kräusel, W. 1953. Cyclopelta winteri (Bryozoa) aus dem Mitteldevon der Eifel. Senckebergiana 34(1-3): 43-52.

Kräusel, W. 1954. Cyclopelta winteri (Bryozoa) aus der corbis-Bank des Oberharzer Mittel-Devons (Bryoz.). Senckenbergiana 34 (4-6): 246. 
Kräusel, W. 1956. Bryozoen-Arten F. A. Roemer's (Fenestellidae) aus dem deutschen Devon. Senckenbergiana Lethaea 37(1-2): 59-64.

Kräusel, W. 1957. Loculipora Hall aus dem Mittel-Devon des Rheinischen Schiefergebirges und des Harzes. Senckenbergiana Lethaea 38(5-6): 335-343.

Kräusel, W. 1981. Wuchsformen der Fenestelliden (Bryozoen) aus dem Mitteldevon der Eifel. Der Aufschluss 32(1): 29-36.

Ma, J.-Y., C.J. Buttler, and P.D. Taylor. 2014. Cladistic analysis of the "trepostome" Suborder Esthonioporina and the systematics of Palaeozoic bryozoans. In Bryozoan Studies 2013, eds. A. Rosso, P.N. Wyse Jackson, and J.S. Porter. Studi Trentini di Scienze Naturali 94: $153-161$

Maurer, F. 1885. Die Fauna der Kalke von Waldgirmes bei Gießen. Darmstadt: Bergsträsser.

McKinney, F.K. 1998. Avicularia-like structures in a Paleozoic fenestrate bryozoan. Journal of Paleontology 72: 819-826.

McKinney, F.K., and J. Kř́žz. 1986. Lower Devonian Fenestrata (Bryozoa) of the Prague Basin, Barrandian area, Bohemia, Czechoslovakia. Fieldiana 1368: 1-90.

McKinney, F.K., P.D. Taylor, and S. Lidgard. 2003. Predation on bryozoans and its reflection in the fossil record. In Predator-prey interactions in the fossil record, eds. P.H. Kelley, M. Kowalewski, and T.A. Hansen, 239-261. New York: Kluwer.

Miller, T.G. 1962. Some Wenlock fenestrate Bryozoa. Palaeontology 5: 540-549.

Morozova, I.P. 1974. Revision of the bryozoan genus Fenestella. Paleontologicheskii Zhurnal 1974(2): 54-67. (in Russian).

Morozova, I.P. 1987. Morphogenesis, system and colonial integration in Bryozoa of the Order Fenestrida. Trudy Paleontologischeskogo Instituta Akademii Nauk SSSR 222: 70-88. (in Russian).

Morozova, I.P. 2001. Bryozoans of the Order Fenestellida. Trudy Paleontologicheskogo Instituta Rossijskoj Akademii Nauk 277: 1-176. (in Russian).

Morozova, I.P., and V.D. Lavrentjeva. 1998. New bryozoans of the Family Semicosciniidae. Paleontologicheskii Zhurnal 1998(2): 53-59. (in Russian).

Nekhoroshev, V.P. 1926. Middle Devonian bryozoans of northwest Mongolia with a description of the microscopic method for the determination of fenestellids. Trudy Geologicheskogo Muzeya AN SSSR 1: 1-28. (in Russian).

Nekhoroshev, V.P. 1928. Über die Entdeckung der Gattung Semicoscinium Prout in den mitteldevonischen Ablagerungen der Eifel und über die Bedeutung dieses Fundes. Centralblatt für Mineralogie, Geologie und Paläontologie (B: Geologie und Paläontologie) 1928: 476-478.

Počta, P. 1894. Bryozoaires, Hydrozoares et partie des Anthozoaries. In Systême Silurien du Centre de la Bohême par Joachim Barrande. Recherches Paleontologiques 8(1): 1-230.

Prout, H.A. 1859. Third series of descriptions of Bryozoa from the Paleozoic rocks of western states and territories. Transactions of St. Louis Academy of Sciences (series 3) 1: 443-452.

Smith, A.M., M.M. Key Jr., and D.P. Gordon. 2006. Skeletal mineralogy of bryozoans: Taxonomic and temporal patterns. Earth Science Reviews 78(3-4): 287-306.

Struve, W., and R. Werner. 1982. The Lower/Middle Devonian boundary and the Eifelian Stage in the "Type Eifelian" region. In Field meeting on Lower and Lower Middle Devonian stages in the Ardenno-Rhenish type area, guidebook, eds. G. Plodowski, R. Werner, and W. Ziegler, 81-151. Frankfurt am Main.

Suárez-Andrés, J.L., and F.K. McKinney. 2010. Revision of the Devonian fenestrate bryozoan genera Cyclopelta Bornemann, 1884, and Pseudoisotrypa Prantl, 1932, with a description of a rare fenestrate growth habit. Revista Española de Paleontología 25 (2): 123-138.

Suárez-Andrés, J.L., and P.N. Wyse Jackson. 2017. Fenestrate Bryozoa of the Moniello Formation (Lower-Middle Devonian, NW Spain). Bulletin of Geosciences 92(2): 153-183.

Waschurova, L.I. 1964. Bryozoa from the Lower Devonian of the Zeravshan and Turkestan Ranges. Trudy Upravlenia Geoligii i Okhrany Nedr Pri Sovete Ministrov Tadzhikskoi SSSR, Paleontologia i Stratigrafia 1: 75-168. (in Russian).

Xia, F. 2002. Fenestrate Bryozoa with avicularia-like structures from the Middle Jurassic of north Tibet and the origin of cheilostome bryozoans. Acta Micropalaeontologica Sinica 19(3): 237-255. 